\title{
Phylogeography and population structure of the grape powdery mildew fungus, Erysiphe necator, from diverse Vitis species
}

\author{
Marin Talbot Brewer, Michael G Milgroom
}

\begin{abstract}
Background: The grape powdery mildew fungus, Erysiphe necator, was introduced into Europe more than 160 years ago and is now distributed everywhere that grapes are grown. To understand the invasion history of this pathogen we investigated the evolutionary relationships between introduced populations of Europe, Australia and the western United States (US) and populations in the eastern US, where E. necator is thought to be native. Additionally, we tested the hypothesis that populations of $E$. necator in the eastern US are structured based on geography and Vitis host species.

Results: We sequenced three nuclear gene regions covering 1803 nucleotides from 146 isolates of E. necator collected from the eastern US, Europe, Australia, and the western US. Phylogeographic analyses show that the two genetic groups in Europe represent two separate introductions and that the genetic groups may be derived from eastern US ancestors. Populations from the western US and Europe share haplotypes, suggesting that the western US population was introduced from Europe. Populations in Australia are derived from European populations. Haplotype richness and nucleotide diversity were significantly greater in the eastern US populations than in the introduced populations. Populations within the eastern US are geographically differentiated; however, no structure was detected with respect to host habitat (i.e., wild or cultivated). Populations from muscadine grapes,

$V$. rotundifolia, are genetically distinct from populations from other Vitis host species, yet no differentiation was detected among populations from other Vitis species.

Conclusions: Multilocus sequencing analysis of the grape powdery mildew fungus is consistent with the hypothesis that populations in Europe, Australia and the western US are derived from two separate introductions and their ancestors were likely from native populations in the eastern US. The invasion history of E. necator follows a pattern consistent with plant-mediated dispersal, however, more exhaustive sampling is required to make more precise conclusions as to origin. E. necator shows no genetic structure across Vitis host species, except with respect to $V$. rotundifolia.
\end{abstract}

\section{Background}

Introduced pathogens have led to devastating epidemics in naïve host populations that lack evolved defences, as demonstrated by the plant pathogen Cryphonectria parasitica, the fungus that causes chestnut blight. Its introduction from Asia [1] practically eliminated the American chestnut (Castanea dentata) and markedly altered the species composition of forests throughout eastern North America. Source pathogen populations

\footnotetext{
* Correspondence: mgm5@cornell.edu

Department of Plant Pathology and Plant-Microbe Biology, Cornell University, Ithaca, NY 14853, USA
}

are expected to be more diverse than introduced populations because introduced populations have smaller effective population sizes due to losses in genetic diversity from population bottlenecks and genetic drift associated with small founder population sizes $[2,3]$. However, this pattern could be reversed if multiple divergent lineages from separate sources colonize an area $[4,5]$. Where introductions are few, haplotypes in introduced populations should be a subset of those in the source population [6,7]. Additionally, for sexually reproducing organisms, recombination from sexual reproduction may be more prevalent in source or native

\section{Ciomed Central}


populations, whereas clonal reproduction may dominate in introduced or marginal populations since multiple mating types necessary for sexual reproduction may not be present [8-10]. However, lack of variation in introduced populations can make it difficult to detect recombination.

The focus of this research is the invasion history and population structure of the grape powdery mildew fungus, Erysiphe necator (formerly Uncinula necator), an obligate parasite of Vitis species that was introduced into Europe and, eventually, all other wine-producing regions of the world. Historical records support the hypothesis that the source of the introduction is eastern North America [11]. Powdery mildew was described on grapes in North America in 1834, prior to its discovery in Europe in 1845 [12]. Eastern North America is the centre of origin for many wild species of Vitis that have relatively high levels of resistance to many diseases and pests of grapevines, including powdery mildew [13,14]. After its introduction to Europe, grape powdery mildew was observed throughout all wine-producing regions of the world, including California in 1859 [15] and Australia in 1866 [16]. E. necator most likely dispersed long distances by the movement of grapevines, which were frequently traded between continents in the mid-1800's and later. E. necator remains dormant as mycelium in dormant buds, or as sexual spores in cleistothecia in the bark of vines $[17,18]$.

Population genetic studies on E. necator to date have been limited to introduced populations in Europe and Australia where two distinct, yet sympatric, genetic groups have been consistently found [19-25]. The groups, designated as A and B (or groups I and III in earlier studies), were originally identified using anonymous markers assayed by RAPDs, ISSRs and AFLPs. Subsequent gene sequence analysis detected fixed nucleotide differences between groups at several nuclear loci, including $14 \alpha$-demethylase (CYP51), the internal transcribed spacer (ITS) regions of ribosomal DNA (rDNA) [26], and beta-tubulin (TUB2) [27]. In India, a third genetic group was found, defined by RAPDs and a unique ITS sequence $[19,26]$. Small differences in reproductive fitness [25] and temporal variation have been found between groups A and B [22,23,25,26] leading to the hypothesis that temporal variation between the groups may be maintaining the differentiation by preventing interbreeding [28]. Group A is genetically less diverse than group $B$, thus it has been suggested that it is clonal, whereas group $B$ is sexually reproducing $[19,23]$. Groups A and B produce viable sexual progeny (ascospores) in laboratory crosses [21,22,29], but recombinants have not been found in nature.

We had two major objectives for this study. First, to understand the evolutionary processes that led to the existence of groups $\mathrm{A}$ and $\mathrm{B}$ of $E$. necator in introduced populations, we tested the hypothesis that A and B were derived from separate introductions, as opposed to diverging after their introduction. To address this question, it was essential to study the population structure in eastern North America, the putative source population. Because no information was available on the population genetics of E. necator in North America, our major second objective was to describe the diversity and population structure in the eastern Unites States (US). We tested the hypothesis that if the eastern US population was a potential source of introductions, haplotypes found in introduced populations of Europe, Australia, and the western US would also be found in the eastern US. Moreover, we predicted that populations in the eastern US would have greater haplotype and nucleotide diversity than introduced populations. Finally, we tested the hypotheses that the population in the eastern US is structured by geography, Vitis host species, or host habitat (wild or cultivated Vitis).

\section{Results}

\section{Genetic diversity in eastern US and introduced populations}

We obtained 146 isolates of $E$. necator from diverse wild and cultivated Vitis species collected from the eastern US (northeast, southeast and central) and from cultivated $V$. vinifera from the western US, Europe, and Australia (Table 1; Additional file 1: Table S1). We also collected isolates of powdery mildew (E. necator var. ampelopsidis [30]) from Parthenocissus quinquefolia. We sequenced a total of 1803 nucleotides from three nuclear gene regions: the internal transcribed spacer and the intergenic spacer regions of nuclear rDNA (ITS/ $I G S)$, beta-tubulin (TUB2), and translation elongation factor 1- $\alpha(E F 1-\alpha)$. We were unable to amplify IGS from isolates sampled from $P$. quinquefolia. However, $E$. necator var. ampelopsidis from $P$. quinquefolia is markedly divergent with $94.9 \%, 93.0 \%$, and $91.7 \%$ similarity to the consensus sequence of isolates from Vitis spp. for ITS, TUB2, and EF1- $\alpha$, respectively. For comparison, the lowest sequence similarity within $E$. necator from Vitis spp. was $99.8 \%, 99.5 \%$, and $99.4 \%$. Among isolates of $E$. necator from Vitis spp. there were 37 segregating sites and 45 multilocus haplotypes (Table 2). EF1- $\alpha$ contained the most segregating sites, followed by TUB2, and ITS/IGS. All of the polymorphisms in EF1- $\alpha$ and TUB2 were found in introns or as synonymous substitutions in coding regions.

Based on measurements of Tajima's D [31], ITS/IGS and EF1- $\alpha$ do not deviate from neutral evolution (Table $3)$. However, TUB2 deviates significantly from neutrality in the eastern US population. Significant negative values for Tajima's $D$ can result from population bottlenecks 
Table 1 Vitis host species, host habitats and geographic regions where Erysiphe necator was collected

\begin{tabular}{lccl}
\hline Vitis Host Species & Wild & Cultivated & Host Regions \\
\hline V. vinifera (European wine grape) & & 71 & southeast US, central US, northeast US, western US, Europe, Australia \\
Vinifera hybrids & & 29 & southeast US, central US, northeast US \\
$V$ V. labrusca and labrusca hybrids' ${ }^{2}$ (e.g., 'Concord') & 7 & 9 & southeast US, northeast US \\
$V$. aestivalis & 13 & & southeast US, central US, northeast US \\
$V$. riparia & 12 & & southeast US, central US, northeast US \\
$V$. rotundifolia (muscadine) & 2 & 3 & southeast US \\
\hline
\end{tabular}

${ }^{1}$ vinifera hybrids refer to interspecific hybrids derived from crosses between the European wine grape, $V$. vinifera, and wild American Vitis species other than V. labrusca.

${ }^{2}$ labrusca hybrids (i.e. 'Concord' and 'Niagara'; sometimes referred to as V. labruscana) refer to V. vinifera $\mathrm{x}$ V. labrusca hybrids that are derived primarily from V. labrusca because of repeated backcrossing

${ }^{3}$ Sometimes referred to as Muscadinia rotundifolia.

followed by rapid population expansion or from selective sweeps acting on or near the loci under investigation. Since this effect is not detected across the entire genome, as would be expected with demographic effects, this is suggestive that the deviation from neutrality in TUB2 is from selection.

We estimated several population genetic parameters in the eastern US and introduced populations, including haplotype richness $\left(h_{\mathrm{R}}\right)$, Watterson's theta $\left(\theta_{\mathrm{w}}\right)$, and pairwise nucleotide diversity $(\pi)$. Haplotype richness is significantly greater in the eastern US than in the introduced populations for each locus and the multilocus haplotypes (Table 3), even when adjustments are made for differences in sample size (see Methods). Additionally, there is greater nucleotide polymorphism $\left(\theta_{\mathrm{w}}\right)$ in the eastern US population for TUB2, EF1- $\alpha$ and for all three loci combined. There is greater pairwise nucleotide diversity ( $\pi$ ) for $E F 1-\alpha$ in the eastern US population. However, $\pi$ is greater in the introduced population for ITS/IGS.

\section{Phylogeography}

To determine evolutionary relationships among isolates, we constructed networks for the three gene regions and multilocus haplotypes (Figures 1 and 2). Ancestral haplotypes identified based on rooting probability $[32,33]$ and maximum parsimony using E. necator var. ampelopsidis as an outgroup were from the eastern US in all cases. Based on maximum parsimony the outgroup haplotypes would be at least 23 mutational steps from the putative ancestors for ITS/IGS, 29 steps for TUB2, 35 steps for $E F 1-\alpha$, and at least 87 steps for the combined multilocus haplotype. Because of this degree of divergence TCS did not place the outgroup in the same network. The internal position of haplotypes from eastern North America is particularly noticeable for the multilocus network (Figure 2), whereas all haplotypes of isolates from introduced populations (represented by striped and stippled patterns) are at or near the tips of the network. Isolates from the western US have the same haplotypes (nos. 41 and 43) as isolates in group B from Europe (Table 2; Figures 1 and 2), which suggests that populations in the western US were introduced from Europe. In addition to the 13 isolates from the western US reported here, 17 isolates from California and one from Oregon had the same IGS sequence that is found only in group B (data not shown). We did not sequence additional loci for these isolates from the western US because all were like group B for IGS.

The majority of haplotypes for the individual loci, and especially for the multilocus network, are represented by individuals from the eastern US populations, demonstrating that populations in the eastern US are more diverse than in Europe, Australia and the western US. The sample size from the eastern US population is larger; however, this difference is accounted for in the comparisons of diversity estimates by rarefaction analyses. Although isolates from the central US are represented by diverse haplotypes, they are mostly derived haplotypes at or near the tips of the multilocus network, which suggests that this region is peripheral to the centre of diversity. All isolates obtained from $V$. rotundifolia belonged to two multilocus haplotypes (nos. 34 and 35; labelled ' $M$ ' in Figure 2) at the tips, derived from group A (haplotype no. 33) and not shared by isolates from any other host species.

The haplotype networks show that genetic groups A and $\mathrm{B}$ from introduced populations are distinct from each other at all loci and are derived from North American ancestors (Figures 1 and 2). Because of these differences, and the internal position of North American haplotypes, groups A and B almost certainly represent two separate introductions instead of diverging after introduction. We found no genetic variation among group A isolates, and this same multilocus haplotype (no. 33) was common in the southeastern US in isolates from diverse wild and cultivated host species, including $V$. vinifera, vinifera hybrids, $V$. aestivalis, and $V$. riparia (Additional file 1: Table S1; Table 2). In contrast, we found five multilocus haplotypes (nos. 41-45) forming a 
Table 2 Haplotypes and polymorphic sites among isolates of Erysiphe necator based on partial sequences of three gene regions

\begin{tabular}{|c|c|c|c|c|c|c|}
\hline \multirow[t]{2}{*}{ Haplotype $^{1}$} & \multirow[t]{2}{*}{$N$} & \multicolumn{3}{|c|}{ Polymorphic Sites $^{2}$} & \multirow[t]{2}{*}{ Region $(N)^{3}$} & \multirow[t]{2}{*}{ Host Vitis spp. $(N)^{4}$} \\
\hline & & ITS/IGS & TUB2 & $E F 1-\alpha$ & & \\
\hline 1 (aaa) & 16 & TGGTGG/CGGTC & TGССTTTATCCC & CTCGACCATTTCGC & SE (8), NE (8) & vin (8), hyb (3), aes (2), rip (3) \\
\hline $2(a a b)$ & 4 & $\ldots \ldots / \ldots$ & $\ldots \ldots \ldots$ & $\ldots \ldots c \ldots$ & NE (4) & $\operatorname{vin}(2)$, hyb (1), rip (1) \\
\hline 3 (aac) & 1 & $\ldots \ldots / \ldots$ & $\ldots \ldots \ldots$ & $\ldots \ldots \ldots$ т. & NE (1) & hyb (1) \\
\hline 4 (aad) & 1 & $\ldots \ldots / \ldots$ & $\ldots \ldots \ldots$ & $\ldots \ldots$. . . & SE (1) & aes (1) \\
\hline 5 (aae) & 3 & $\ldots \ldots / \ldots \ldots$ & $\ldots \ldots \ldots \ldots$ & $\ldots$. . .... & NE (3) & hyb (2), lab (1) \\
\hline 6 (aaf) & 4 & $\ldots \ldots / \ldots \ldots$ & $\ldots \ldots \ldots \ldots$ & ........... & NE (4) & hyb (2), lab (1), rip (1) \\
\hline 7 (aag) & 1 & $\ldots \ldots / \ldots \ldots$ & $\ldots \ldots \ldots \ldots$ & TC....... & NE (1) & rip (1) \\
\hline 8 (aah) & 7 & $\ldots \ldots / \ldots \ldots$ & $\ldots \ldots \ldots \ldots$ & TC..А.... & SE (2), NE (5) & hyb (3), lab (1), aes (1), rip (2) \\
\hline 9 (aai) & 6 & $\ldots \ldots / \ldots \ldots$ & $\ldots \ldots \ldots \ldots$ & $\ldots \ldots \ldots \ldots \mathrm{T}$ & SE (1), NE (5) & $\operatorname{vin}(1)$, lab (1), aes (3), rip (1) \\
\hline 10 (aaj) & 6 & $\ldots \ldots / \ldots \ldots$ & $\ldots \ldots \ldots \ldots$ & $\ldots \ldots$ т... & NE (6) & hyb (5), lab (1) \\
\hline 11 (aak) & 5 & $\ldots \ldots / \ldots \ldots$ & $\ldots \ldots \ldots \ldots$ & $\ldots$ т.... & SE (3), C (1), NE (1) & vin (2), hyb (2), rip (1) \\
\hline 12 (aal) & 2 & $\ldots \ldots / \ldots$ & $\ldots \ldots \ldots \ldots$ & $\ldots \ldots \ldots$ с. т & SE (1), NE (1) & $\operatorname{vin}(2)$ \\
\hline 13 (aam) & 1 & $\ldots \ldots / \ldots$ & $\ldots \ldots \ldots \ldots$ & $\ldots$. G.... C. T & NE (1) & $\operatorname{vin}(1)$ \\
\hline $14(a b a)$ & 3 & $\ldots \ldots / \ldots \ldots$ & $\ldots$ т...... & $\ldots \ldots \ldots \ldots$ & SE (3) & $\operatorname{vin}(1)$, lab (1), aes (1) \\
\hline $15(a b b)$ & 1 & $\ldots \ldots / \ldots$ & $\ldots$ Т...... & $\ldots \ldots$. . . . & SE (1) & lab (1) \\
\hline $16(a b l)$ & 1 & $\ldots \ldots / \ldots \ldots$ & $\ldots$ т. . . & $\ldots \ldots \ldots$ с. т & $C(1)$ & hyb (1) \\
\hline 17 (abn) & 1 & $\ldots \ldots / \ldots \ldots$ & $\ldots$ т...... & $\ldots \ldots \ldots \ldots$ & $C(1)$ & rip (1) \\
\hline 18 (ach) & 1 & $\ldots \ldots / \ldots$ &.$c \ldots \ldots \ldots$ & TC........ & $C(1)$ & $\operatorname{vin}(1)$ \\
\hline $19(\mathrm{acl})$ & 2 & $\ldots \ldots / \ldots$ &.$C \ldots \ldots \ldots$ & $\ldots \ldots \ldots$ с & $C(2)$ & vin (1), hyb (1) \\
\hline 20 (aco) & 1 & $\ldots \ldots / \ldots \ldots$ &. . . . . . . & .А..... С. Т & $C(1)$ & hyb (1) \\
\hline $21(a d b)$ & 1 & $\ldots \ldots / \ldots \ldots$ & $c \ldots \ldots \ldots$ & $\ldots \ldots \ldots$. . . & $\mathrm{NE}(1)$ & $\operatorname{vin}(1)$ \\
\hline 22 (aeh) & 2 & $\ldots \ldots / \ldots \ldots$ & $\ldots \ldots$. & TC........ & NE (2) & hyb (2) \\
\hline $23(a f n)$ & 2 & $\ldots \ldots / \ldots \ldots$ & $\ldots \ldots$ т... & $\ldots \ldots \ldots$ A & $C(2)$ & $\operatorname{vin}(2)$ \\
\hline 24 (agk) & 1 & $\ldots \ldots / \ldots \ldots$ & $\ldots \ldots \ldots \mathrm{T}$ & $\ldots \mathrm{T} \ldots \ldots \mathrm{T}$ & SE (1) & $\operatorname{vin}(1)$ \\
\hline 25 (baa) & 3 & $\ldots \ldots / \ldots \mathrm{T}$ & $\ldots \ldots \ldots$ & $\ldots \ldots \ldots \ldots$ & SE (1), NE (2) & lab (3) \\
\hline $26(b a b)$ & 2 & $\ldots \ldots / \ldots \mathrm{T}$ & $\ldots \ldots \ldots$ & $\ldots \ldots$. . . . & NE (2) & $\operatorname{vin}(1), \operatorname{lab}(1)$ \\
\hline 27 (bai) & 1 & $\ldots \ldots / \ldots \mathrm{T}$ & $\ldots \ldots \ldots$ & $\ldots \ldots \ldots \ldots \mathrm{T}$ & $\mathrm{NE}(1)$ & lab (1) \\
\hline $28(b a l)$ & 1 & $\ldots \ldots / \ldots \mathrm{T}$ & $\ldots \ldots \ldots \ldots$ & $\ldots \ldots \ldots$ с. & NE (1) & $\operatorname{vin}(1)$ \\
\hline 29 (bba) & 1 & $\ldots \ldots / \ldots \mathrm{T}$ & $\ldots$ Т...... & $\ldots \ldots \ldots \ldots$ & NE (1) & hyb (1) \\
\hline $30(b b l)$ & 1 & $\ldots \ldots / \ldots \mathrm{T}$ & $\ldots$ т...... & $\ldots \ldots$. & $\mathrm{NE}(1)$ & hyb (1) \\
\hline 31 (bha) & 2 & $\ldots \ldots / \ldots \mathrm{T}$ & . Т..А.... & $\ldots \ldots \ldots \ldots$ & NE (2) & lab (2) \\
\hline 32 (bia) & 1 & $\ldots \ldots / \ldots \mathrm{T}$ & $\ldots \ldots$. . . & $\ldots \ldots \ldots \ldots$ & NE (1) & lab (1) \\
\hline $33(c b a)$ & 23 & $\ldots \ldots / \ldots \mathrm{CT}$ & $\ldots$ т...... & $\ldots \ldots \ldots \ldots$ & $\mathrm{SE}(8), \mathrm{EU}(13), \mathrm{AU}(2)$ & vin (18), hyb (1), aes (2), rip (2) \\
\hline $34(d b a)$ & 1 & $\ldots \ldots / \ldots \mathrm{CCT}$ & $\ldots$ т...... & $\ldots \ldots \ldots \ldots$ & SE (1) & $\operatorname{rot}(1)$ \\
\hline 35 (dja) & 4 & $\ldots \ldots / \ldots \mathrm{CCT}$ & $\ldots$ TG $\ldots . .$. & $\ldots$ & SE (4) & $\operatorname{rot}(4)$ \\
\hline 36 (eba) & 1 & $\ldots$. . $/ \ldots$. & $\ldots$ т...... & & NE (1) & $\operatorname{vin}(1)$ \\
\hline 37 (fae) & 1 & . Т.../... & $\ldots \ldots \ldots \ldots$ & $\ldots$ А. . . . & SE (1) & hyb (1) \\
\hline 38 (gac) & 1 & $\ldots \ldots$ A $/ \ldots$ & $\ldots \ldots \ldots \ldots$ & $\ldots \ldots \ldots$ т. & $C(1)$ & hyb (1) \\
\hline 39 (hac) & 1 & $\ldots$ А... $\ldots$ & $\ldots \ldots \ldots \ldots$ & $\ldots \ldots \ldots$ т. & SE (1) & aes (1) \\
\hline 40 (ika) & 1 & $\ldots \mathrm{A} \ldots / \ldots \mathrm{T}$ & . T.С..... & $\ldots \ldots$ & $\mathrm{NE}(1)$ & aes (1) \\
\hline 41 (jai) & 18 & С.../T... & $\ldots \ldots \ldots$ & $\ldots \ldots \ldots \mathrm{T}$ & W (12), EU (6) & $\operatorname{vin}(18)$ \\
\hline 42 (jak) & 1 & С.../T... & $\ldots \ldots \ldots \ldots$ & $\ldots$ т.... & EU (1) & $\operatorname{vin}(1)$ \\
\hline 43 (jli) & 3 & С.../T... & $\ldots \ldots \ldots \mathrm{T}$ & $\ldots \ldots \ldots \ldots \mathrm{T}$ & W (1), EU (2) & $\operatorname{vin}(3)$ \\
\hline $44(j l l)$ & 2 & С.../T... & $\ldots \ldots \ldots \mathrm{T}$ & $\ldots \ldots \ldots$. & EU (2) & $\operatorname{vin}(2)$ \\
\hline 45 (kmi) & 4 & С.../TA... & $\ldots \ldots \ldots$. . & $\ldots \ldots \ldots \ldots \mathrm{T}$ & $\mathrm{AU}(4)$ & $\operatorname{vin}(4)$ \\
\hline
\end{tabular}

${ }^{1}$ Numbers refer to the multilocus haplotypes; letters in parentheses refer to the haplotypes for ITS/IGS (the internal transcribed spacer of rDNA/the intergenic spacer of rDNA), TUB2 (beta-tubulin), and EF1- $\alpha$ (translation elongation factor 1- $\alpha$ ), respectively. Group A is represented by haplotype 33 and group B is represented by haplotypes $41-45$.

${ }^{2}$ Only segregating sites are listed, which correspond to the following nucleotide positions in the referenced GenBank accessions: ITS (GQ255473; total length 591 nucleotides): 48, 84, 86, 170, 420, 462; IGS (GQ255476; 347 nt): 108, 206, 211, 216, 223; TUB2 (GQ255475; 442 nt): 24, 37, 79, 82, 128, 183, 207, 288, 316, 344, 356, 368; $E F 1-\alpha$ (GQ255471; 423 nt): 2, 9, 25, 33, 102, 189, 210, 227, 228, 231, 336, 381, 384, 420.

${ }^{3}$ regions are: $\mathrm{SE}=$ southeast US, $\mathrm{C}=$ central US, NE = northeast US, W = western US, EU = Europe, AU = Australia. $N=$ the number of isolates from each region with the designated haplotype.

${ }^{4}$ hosts are: vin $=V$. vinifera, hyb $=$ vinifera hybrids, lab $=V$. labrusca and labrusca hybrids, aes $=V$. aestivalis, rip $=V$. riparia, rot $=V$. rotundifolia. $N=$ the number of isolates from each host with the designated haplotype. 
Table 3 Haplotype richness, sequence diversity and neutrality estimates for populations of Erysiphe necator

\begin{tabular}{|c|c|c|c|c|c|}
\hline Locus & Population $^{1}$ & Haplotype richness $\left(h_{R}\right)^{2}$ & Watterson's $\theta\left(\theta_{\mathrm{w}}\right)$ & $\pi$ & Tajima's $D$ ( $P$-value) \\
\hline \multirow[t]{3}{*}{ ITS/IGS } & Eastern US & $6(9)^{3}$ & 0.00123 & 0.00085 & $-1.167(0.108)$ \\
\hline & Introduced & 3 & 0.00123 & 0.00217 & $1.901(0.975)$ \\
\hline & & $P=0.013$ & $P=0.485$ & $P=1.000$ & \\
\hline \multirow[t]{3}{*}{ TUB2 } & Eastern US & $7(11)$ & 0.00314 & 0.00159 & $-1.598(0.013)$ \\
\hline & Introduced & 4 & 0.00157 & 0.00192 & $0.478(0.727)$ \\
\hline & & $P=0.049$ & $P=0.050$ & $P=0.833$ & \\
\hline \multirow[t]{3}{*}{$E F 1-\alpha$} & Eastern US & $11(15)$ & 0.00601 & 0.00472 & $-0.680(0.270)$ \\
\hline & Introduced & 4 & 0.00164 & 0.00142 & $-0.281(0.411)$ \\
\hline & & $P<0.001$ & $P=0.001$ & $P=0.001$ & \\
\hline \multirow[t]{3}{*}{ Combined } & Eastern US & $21(40)$ & 0.00282 & 0.00194 & - \\
\hline & Introduced & 6 & 0.00141 & 0.00193 & - \\
\hline & & $P<0.001$ & $P=0.001$ & $P=0.497$ & \\
\hline
\end{tabular}

${ }^{1}$ The introduced population comprises Europe, Australia and the western US; the eastern US comprises northeast, southeast and central US (Table 1).

${ }^{2}$ To account for sample size differences in eastern US $(N=103)$ and introduced populations $(N=43)$, we used rarefaction analysis [66] for haplotype richness, $\theta_{\mathrm{w}}$ and $\pi$ in the native population. Diversity estimates where the eastern US population is significantly more diverse than the introduced populations $(P<0.05)$ are in bold.

${ }^{3}$ Numbers in parentheses are the number of observed haplotypes among the 103 isolates from the eastern US population without correction by rarefaction analysis.

discrete lineage in group B; none of these multilocus haplotypes was found in eastern North America. However, group B does not differ from the eastern US population at all loci (Figure 1; Table 2). It differs for ITS/ $I G S$, yet shares several haplotypes for EF1- $\alpha$ and TUB2 with the eastern US population.

\section{Population differentiation}

Differentiation was estimated between the eastern US and introduced populations, and among geographic regions, Vitis host habitats, and Vitis host species in eastern US. Eastern US and introduced populations are significantly differentiated (Table 4). Within the eastern US, we detected significant differentiation among geographic regions (southeast US, northeast US, and central US). Geographic differentiation within the eastern US was detected when isolates from all hosts were included in the analysis. Because many hosts are more abundant in particular geographic regions (for example, $V$. riparia in the northeast US or $V$. rotundifolia in the southeast US), we conducted tests of geographic subdivision on isolates collected only from $V$. vinifera and vinifera hybrid hosts, which are found abundantly among the three regions, to avoid confounding host and geography. Geographic subdivision was still evident when the analyses only included isolates from $V$. vinifera and vinifera hybrid hosts (Table 4).

There was no differentiation between populations from wild and cultivated host habitats or among host species within geographic regions (Table 4), except when isolates from $V$. rotundifolia were included in the analyses.

\section{Discussion}

\section{Patterns of introduction and invasion}

The multilocus haplotype network (Figure 2) demonstrates that the eastern US population is ancestral to the introduced populations [32,33]. Therefore, our results are consistent with the hypothesis that $E$. necator was introduced into Europe from eastern North America [11] because populations in Italy and France are derived from North American ancestors. Additionally, populations in California share haplotypes with populations from Europe, suggesting the possibility that they could have been introduced from Europe; the reverse direction of introduction is less likely given the historical records of trade in grapevines and that grape powdery mildew was first observed in Europe in 1845, but not in California until 1859. However, we cannot make any firm conclusions because we do not know which genetic group, A or B, was introduced into Europe first. Populations in the eastern US are more genotypically diverse than those in Europe, Australia and the western US. Several of the haplotypes for individual loci in the introduced populations were found in eastern North America, which is expected when comparing source and introduced populations. An alternative hypothesis, that E. necator was introduced into Europe from Japan has been suggested [34], but there is no evidence to support this claim and we were unable to obtain samples from Japan for this study.

At least two haplotypes of the grape powdery mildew fungus, progenitors of groups $\mathrm{A}$ and $\mathrm{B}$, were introduced and successfully invaded Europe and Australia. If there 


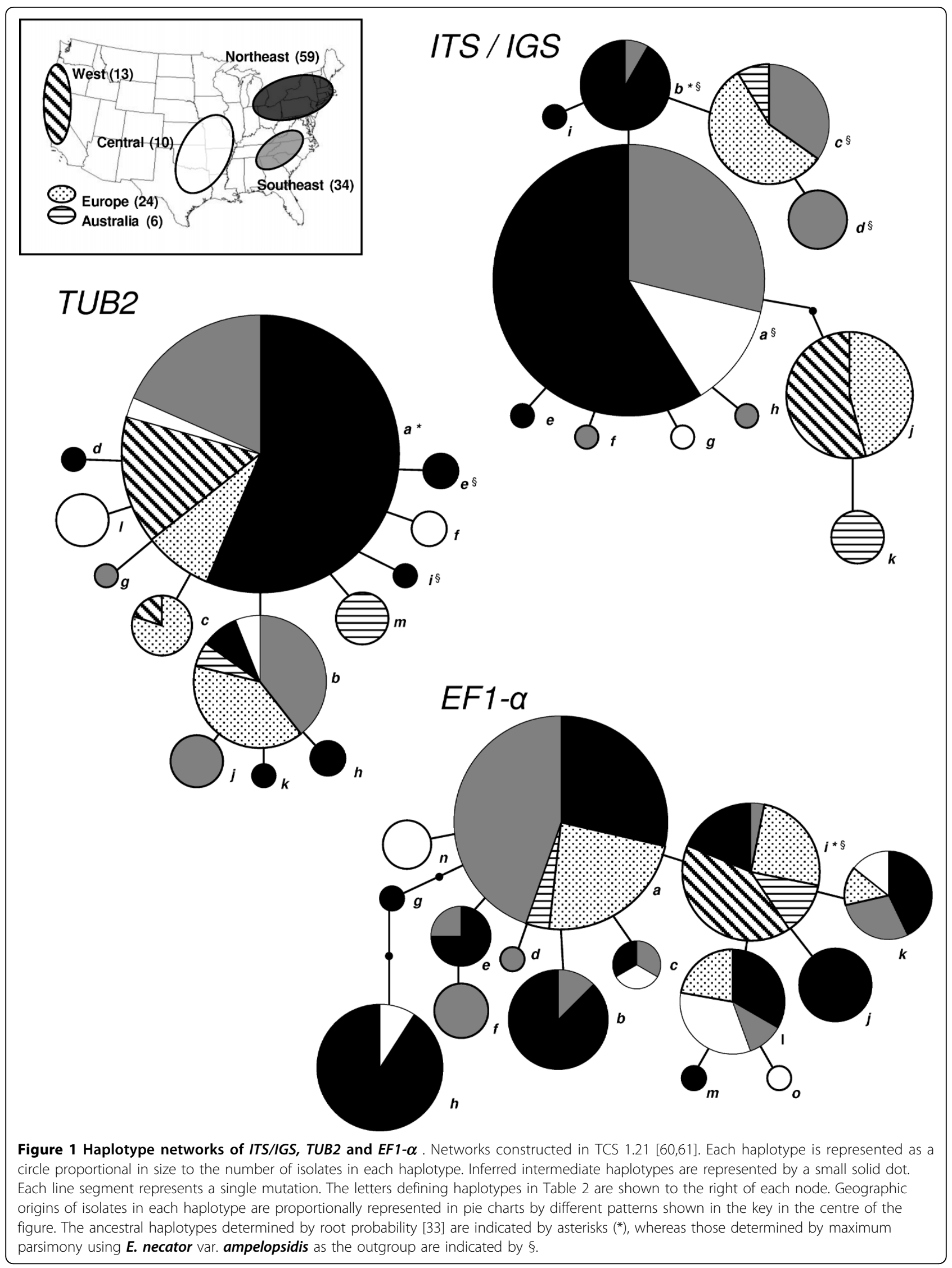




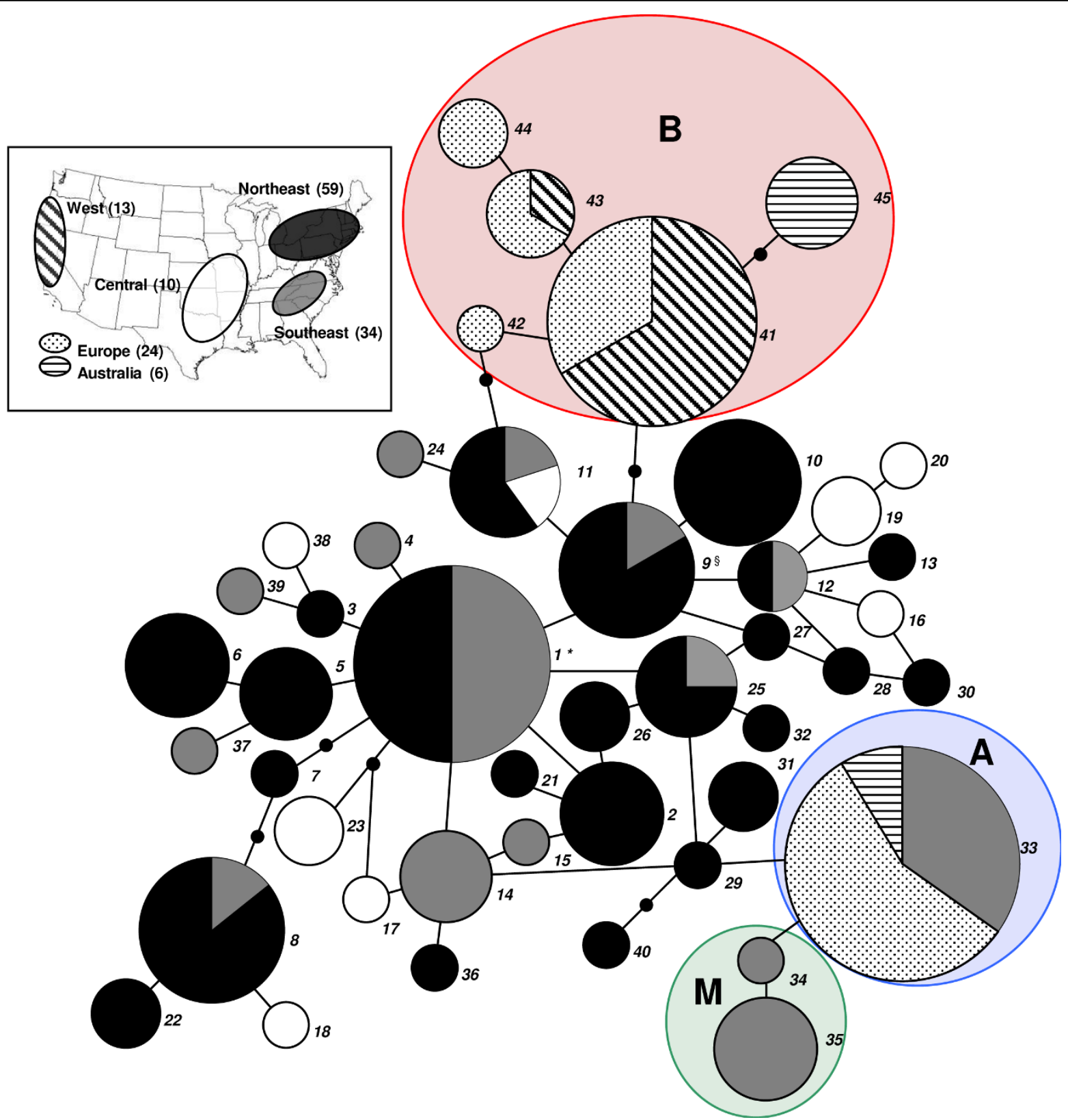

Figure 2 Multilocus haplotype network for Erysiphe necator. Network constructed in TCS 1.21 [60,61]. Each haplotype is represented as a circle proportional in size to the number of isolates in each haplotype. Inferred intermediate haplotypes are represented by a small solid dot. Each line segment represents a single mutation. The numbers defining multilocus haplotypes in Table 2 are shown to the right of each node. Geographic origins of isolates in each haplotype are proportionally represented in pie charts by different patterns shown in the key in the upper left. The haplotypes that include group B isolates are enclosed in a magenta ellipse and marked with a ' $\mathrm{B}$ '; the haplotype that includes group A isolates is enclosed in a green ellipse and marked with an ' $A$ '; and the haplotypes that include isolates from muscadine grapes (V. rotundifolia) are enclosed in a blue ellipse and are marked with an ' $\mathrm{M}$ '. The ancestral haplotype determined by root probability [33] is indicated by an asterisk $\left({ }^{*}\right)$, whereas that determined by maximum parsimony using $\boldsymbol{E}$. necator var. ampelopsidis as an outgroup is indicated by $\S$.

had been a single introduction, individuals in the introduced populations would represent a monophyletic group; the single introduction hypothesis can be rejected based on the relationships of group A and B haplotypes in the multilocus network (Figure 2). The introductions, and successful invasions, may have occurred at separate times or multiple, distinct haplotypes may have been introduced during a single event. Previous studies in French and Australian populations of E. necator, based on anonymous markers, also found greater diversity in 
Table 4 Population structure of Erysiphe necator by geographic region and host species

\begin{tabular}{|c|c|c|}
\hline Populations compared (sample sizes are in parentheses) & $S_{\mathrm{nn}}^{1}$ & $H_{\mathrm{ST}}{ }^{1}$ \\
\hline Eastern US (103) vs. introduced (43) populations & $\begin{array}{l}0.9182 \\
(<0.001)\end{array}$ & $\begin{array}{l}0.0627 \\
(<0.001)\end{array}$ \\
\hline \multicolumn{3}{|l|}{ Within the eastern US } \\
\hline $\begin{array}{l}\text { by geographic region } \\
\text { northeast (59) vs. southeast (34) vs. central (10) }\end{array}$ & $\begin{array}{l}0.6856 \\
(<0.001)\end{array}$ & $\begin{array}{l}0.0280 \\
(<0.001)\end{array}$ \\
\hline $\begin{array}{l}\text { by geographic region on Vitis vinifera and vinifera hybrid hosts } \\
\text { northeast (33) vs. southeast (15) vs. central (9) }\end{array}$ & $\begin{array}{c}0.6384 \\
(<0.001)\end{array}$ & $\begin{array}{l}0.0396 \\
(0.001)\end{array}$ \\
\hline $\begin{array}{l}\text { by host agro-ecological habitat }{ }^{2} \\
\text { cultivated (59) vs. wild (34) hosts }\end{array}$ & $\begin{array}{l}0.5733 \\
(0.133)\end{array}$ & $\begin{array}{l}0.0002 \\
(0.407)\end{array}$ \\
\hline $\begin{array}{l}\text { by host species within the northeast US } \\
\text { V. vinifera (13) vs. vinifera hybrid (20) vs. V. labrusca (10) vs. V. riparia (8) }\end{array}$ & $\begin{array}{l}0.3532 \\
(0.064)\end{array}$ & $\begin{array}{l}0.0051 \\
(0.333)\end{array}$ \\
\hline $\begin{array}{l}\text { by host species within the southeast US including V. rotundifolia } \\
\text { V. rotundifolia (5) vs. V. vinifera (11) vs. vinifera hybrid (4) vs. V. labrusca (3) vs. V. aestivalis (9) }\end{array}$ & $\begin{array}{l}0.3529 \\
(0.008)\end{array}$ & $\begin{array}{l}0.0857 \\
(0.007)\end{array}$ \\
\hline $\begin{array}{l}\text { by host species within the southeast US excluding V. rotundifolia } \\
\text { V. vinifera (11) vs. vinifera hybrid (4) vs. V. labrusca (3) vs. V. aestivalis (9) }\end{array}$ & $\begin{array}{l}0.2552 \\
(0.712)\end{array}$ & $\begin{array}{r}-0.0179 \\
(0.709)\end{array}$ \\
\hline
\end{tabular}

group B than in group A $[21,23]$ and it has been hypothesized that group A is predominantly asexual, while group $B$ undergoes sexual recombination. Most studies have shown that group A is dominated by a single mating type $[19,21,23]$. We expected to find both genetic groups from the introduced populations in the eastern US population. However, we found isolates in the southeastern US with the same multilocus haplotype as that in group A, but we did not find any with the same haplotype as those in group B. Group B haplotypes may have diverged by genetic drift from the original founders since the first introductions into Europe more than 160 years ago. Sexual reproduction and recombination in group B, coupled with selection for new haplotypes on a different host species and in environmental conditions in Europe, could also have led to divergence. Alternatively, our sample size in eastern North America may not have been large enough to include haplotypes that are less common in the eastern US population, which by chance could have been introduced into Europe. An alternative explanation is that the unique alleles specific to genetic group B came from an entirely different source, which we did not sample for this study.

Genotypic diversity was significantly greater in the eastern US population than in introduced populations, although measures of gene diversity were not always greater (Table 3). In fact, pairwise nucleotide diversity $(\pi)$ was significantly greater for ITS/IGS in the introduced population. One explanation for this finding is that the occurrence of two distinct genetic groups in the introduced populations results in high gene diversity because of fixed nucleotide differences between lineages, but low genotypic diversity because there is little or no variation within groups. This discrepancy is similar to finding high gene diversity combined with low genotypic diversity in clonal diploid populations with fixed heterozygosity [35,36]. Multiple introductions of distinct lineages from different sources into new ranges can result in greater diversity than expected during an invasion $[4,5]$. Additionally, gene diversity was overestimated in Europe and Australia because our samples were not random, but rather were artificially constructed with roughly equal numbers of isolates from the two genetic groups, whereas group B is typically found at a greater frequency than group A in populations in Europe [19,22-25]. Moreover, the lack of diversity within groups $A$ and $B$ validated our strategy of sequencing relatively small samples from Europe and Australia where extensive sampling only found these two discrete groups [19-25]. Haplotypic (or allelic) richness is one of the best measures for reductions in diversity associated with population bottlenecks because rare haplotypes are often lost during founder events even if overall gene diversity is not largely affected [2].

Our results are consistent with historical records of the movement of grapevines and plant-mediated 
introductions of E. necator into Europe, California, and Australia. After grape powdery mildew spread throughout Europe by the mid-1850 s, additional vines were imported from eastern North America as sources of resistance. Unfortunately, this resulted in the introduction of additional grape pests and diseases into Europe, including the phylloxera aphid and downy mildew [37,38]. Additional importations of grapevines from eastern North America for resistance to these pests/diseases may have led also to additional introductions of $E$. necator. Secondary introductions of E. necator from Europe into California and Australia are also consistent with historical records of the movement of grapevines. During the 1850's and 1860's large collections of $V$. vinifera were brought to California from Europe [39]. Powdery mildew was first described in California in 1859 and in Australia in $1866[15,16]$, so it is likely that it was introduced on vines imported at this time. Two of the four group B multilocus haplotypes found in Europe are also found in the western US. It is not clear why both genetic groups were introduced into Australia, but only group B is present in California. It is possible that group $\mathrm{A}$ is present in California, but at such a low frequency that we did not sample it. Nevertheless, it is surprising that since its introduction over 150 years ago, additional genotypes of $E$. necator have not been successfully introduced by the movement of vines from the eastern US to Europe, Australia or the western US.

\section{Absence of host specificity among Vitis host species, except $V$. rotundifolia}

With the exception of specialization on muscadine grapes, $V$. rotundifolia, we found no genetic differentiation among populations from Vitis host species. This was not unexpected. The best-studied powdery mildew fungus, Blumeria graminis, shows specialization among host genera rather than among species within a genus [40,41]. Similarly, E. necator demonstrates host specialization at the level of host genus. Gadoury and Pearson [42] showed that $E$. necator var. ampelopsidis sampled from $P$. quinquefolia was only rarely pathogenic on Vitis species, and then only with low virulence. Multilocus sequencing of $E$. necator var. ampelopsidis, as in the formae speciales of B. graminis, showed that this type of marked host specialization correlates to marked genetic divergence from E. necator on Vitis. Alternatively, there may be population divergence of $E$. necator among Vitis hosts, but we are not able to detect it with the conserved genes used in this study. Other fungi show specialization at the level of host species. For example, microsatellite markers, which are more polymorphic than multilocus sequences, allowing for better detection of differentiation, showed specialization of Microbotryum violaceum at the level of host species [43]. The lack of specialization could be also explained by recent colonization of Vitis hosts by E. necator or recent diversification of Vitis species in North America. In closely related species or populations undergoing speciation, genetic divergence may only be evident at one or a few loci involved in adaptation and reproductive isolation [44].

We found that $E$. necator populations from muscadines are genetically distinct from populations on other Vitis species. Although, the haplotypes of muscadine isolates differ from those from other Vitis species by one or two mutations there is a strong phenotypic difference that is a potential isolating mechanism. Another study demonstrated marked host specialization to muscadine in laboratory inoculations, but not among other Vitis species [45]. Although isolates from muscadines could infect other Vitis species in the lab, we did not find haplotypes from the muscadine lineage from other Vitis species in the field even when they were sympatric with muscadines. Populations of $E$. necator from muscadine and other Vitis species could be in the early stages of speciation resulting from host specialization. Alternatively, muscadine isolates may have alleles that evade recognition by host defences in a gene-for-gene interaction. Resistance to powdery mildew controlled by a single, but complex, genetic locus has been demonstrated in muscadines, which is a source of resistance in breeding programs [46]. It is important to test any new resistant cultivars derived from muscadines with diverse powdery mildew populations from the regions where muscadines are endemic to ensure that the resistance would be durable.

Population differentiation of E. necator was not detected between wild and cultivated hosts. In some cases, crop domestication can lead to the divergence of pathogen populations on wild relatives and crop plants [47]. Moreover, management strategies or high-density cultivation of crop plants can lead to population differentiation between pathogens from natural ecosystems and agricultural ecosystems [48]. The lack of population structure in E. necator indicates that gene flow is presently occurring or has occurred historically between the powdery mildew populations from wild and cultivated hosts.

\section{Conclusions}

Our results are consistent with the hypotheses that populations of the grape powdery mildew fungus, E. necator, in Europe are derived from two separate introductions and that their ancestors were likely from native populations in the eastern US. Multilocus sequencing analysis and historical records are also consistent with the hypothesis that the initial introductions into Europe were followed by secondary introductions from Europe into the western US and Australia and were likely the result of plant-mediated dispersal in the 
grapevines that were frequently traded between continents during the time of introductions. Within the eastern US, populations of $E$. necator do not demonstrate divergence based on host habitat or Vitis host species, with the exception of specialization to muscadine grapes, $V$. rotundifolia.

\section{Methods}

\section{Grape powdery mildew pathosystem}

Powdery mildew fungi are haploid ascomycetes that are obligate parasites of plants that produce colonies of superficial hyphae and asexual spores (conidia). E. necator infects Vitis species and other members of the Vitaceae. E. necator can also reproduce sexually if individuals of both of the two mating types are present [42].

Diverse wild Vitis species are found throughout eastern North America [49], with many of the species demonstrating at least some susceptibility to powdery mildew [50]. We sampled E. necator from cultivated grapes and from four of the most common wild species: $V$. riparia, $V$. aestivalis, $V$. labrusca, and $V$. rotundifolia (Table 1). V. riparia is common in colder regions of central and northeastern North America. Both $V$. aestivalis and $V$. labrusca are distributed throughout the northeastern US and the higher elevations in the southeastern US. The muscadine grape, $V$. rotundifolia, which is endemic to and widely distributed throughout the southeastern US, has considerable resistance to powdery mildew [51], and is genetically and morphologically distinct from other Vitis spp., such that it is sometimes considered to be in a separate genus, Muscadinia [52].

Cultivated varieties grown throughout eastern North America are also diverse. Interspecific hybrids derived from crosses between the European wine grape, V. vinifera, and wild American Vitis species are common as cultivated vines [53]. Cultivated labrusca hybrids (i.e. 'Concord' and 'Niagara'; sometimes referred to as V. labruscana) were derived mostly from backcrossing to $V$. labrusca and are grown in colder climates of eastern North America. In contrast to the diversity of hosts in eastern North America, most other major wine-producing regions are dominated by $V$. vinifera, which is native to Eurasia [54] and highly susceptible to E. necator [55].

\section{Sampling, isolate maintenance and DNA extraction}

We sampled E. necator from the eastern US (northeast, southeast, central) and western US (Additional file 1: Table S1). Most of our sampling from wild host species in the southeast was limited to higher elevations because we were not able to find mildew on wild species other than $V$. rotundifolia at lower elevations of the coastal plain. We speculate that this was due to high temperatures and drought that were not conducive to mildew for several weeks prior to our sampling in 2008. Samples from the eastern US were collected to maximize the diversity of host species and host habitats. Samples from France, Italy and Australia were obtained from collaborators who generously sent genomic DNA from $E$. necator isolates collected from cultivated $V$. vinifera and previously identified as genetic group A or B (Additional file 1: Table S1). In this respect, samples from France, Italy and Australia do not represent random samples but they do reflect the diversity found in each country. Populations of E. necator in Europe and Australia have been extensively sampled across broad geographic regions [19-24]. Among these studies, a total of approximately 1000 E. necator isolates were genotyped with various markers, and each study demonstrated that populations are structured into two genetic lineages designated as groups $\mathrm{A}$ and $\mathrm{B}$. We reasoned that additional sampling was not necessary in Europe and Australia for this study because little genetic diversity had been found within the two lineages despite extensive sampling from different cultivars, years, and times of year. We consider that our sampling represents the diversity of isolates in Europe and Australia since the isolates came from both genetic groups across different regions of France, Italy and Australia (we were not able to obtain DNA from other locations with published reports of previous genotyping). In fact, the isolates we sequenced from Australia were identified as having distinct genotypes [21], representative of the total genetic diversity found there previously. Cultivated $V$. vinifera is the only host plant E. necator was sampled from in Europe and Australia because this is the dominant species present in these regions. Therefore, we did not sample from wild species outside of the eastern US.

Isolates of powdery mildew from Parthenocissus quinquefolia, also in the Vitaceae, were collected in Ithaca, NY, USA for comparison with powdery mildew from Vitis species. Powdery mildew from $P$. quinquefolia is considered variety ampelopsidis of $E$. necator [30]. Isolates from Parthenocissus species exhibit host specialization, although some can infect $V$. vinifera but with greatly reduced growth compared to isolates from $V$. vinifera [42].

Mildew isolates were maintained as described by Evans et al. [56] on young leaves of $V$. vinifera 'Cabernet Sauvignon' grown in a greenhouse. Leaves were surfacesterilized in $0.6 \%$ sodium hypochlorite for $1.5 \mathrm{~min}$, rinsed twice with sterile distilled water and air dried in a sterile laminar flow hood. Leaves were kept in Petri dishes containing $20 \mathrm{ml}$ of $2 \%$ water agar. Colonies of $E$. necator were initially isolated by touching a mildew colony from an infected leaf to a surface-sterilized leaf. Asexual spores (conidia) from the resulting colonies were transferred 6-12 days later with a sterile pipette tip 
to another surface-sterilized leaf at least once to rid the colonies of contaminants prior to DNA extraction. Isolates were maintained by transferring to new leaves approximately once per month.

For DNA extraction, conidia and hyphae were collected from colonies 2-3 weeks after inoculation by touching a $1-\mathrm{cm}^{2}$ piece of office tape (Scotch Tape, 3M) to the colony multiple times until the tape was covered in fungal tissue. The tape was placed in a $1.5 \mathrm{~mL}$ microcentrifuge tube with $100 \mu \mathrm{L}$ of $5 \%$ chelex [57,58], vortexed for $30 \mathrm{sec}$ and incubated at $95{ }^{\circ} \mathrm{C}$ for $20 \mathrm{~min}$. The solution was vortexed again for 5 sec centrifuged briefly, and the supernatant was removed and used as the DNA template for PCR.

\section{Multilocus sequencing, sequence alignment, and haplotype network construction}

Three nuclear loci were PCR-amplified and sequenced from each isolate. The gene regions we sequenced included: ITS/IGS, TUB2, and EF1- $\alpha$. ITS [26] and TUB2 [27] had been identified previously in E. necator, whereas $I G S$ and EF1- $\alpha$ were identified in E. necator in this study. For ITS, we developed primers ITSEnF: 5'-AAGGATCATTACAGAGCGAGAGG-3' and ITSEnR: 5'-GGATGACCGGACAAAGGTG-3'. For TUB2, we designed primers Bt2c: 5'-CAGACTGGCCAATGCGTA-3' and Bt2d: 5'-AGTTCAGCACCCTCGGTGTA-3' based on the published sequence (GenBank accession no. AY074934) [27]. We identified the IGS region in E. necator with the conserved ascomycete primers IGS-12a and NS1R [59], then developed primer IGSEn1: 5'TTTCGGGGGAAAGCCACCA-3' to pair with NS1R for improved PCR amplification. EF1- $\alpha$ was identified in $E$. necator by designing degenerate primers to conserved regions of EF1- $\alpha$ in Sclerotinia sclerotiorum (GenBank accession no. DQ471086) and Botrytis cinerea (GenBank accession no. DQ471045). We then developed primers EF1-5: 5'-ATAGCGACGATGAGCTGCTT-3' and EF1-6: 5' -TCGAAAAGGTTTGTTGCAGA-3' for improved PCR amplification. The PCR reactions for ITS, IGS, and TUB2 were carried out in a total volume of $25 \mu \mathrm{L}$. Reaction components included $2.5 \mu \mathrm{L}$ of $10 \times$ PCR buffer (Takara Bio, Inc.), $2.5 \mu \mathrm{L}$ dNTPs, $1.25 \mu \mathrm{L}$ of $10 \mu \mathrm{M}$ forward and reverse primers, $0.75 \mathrm{U}$ ExTaq (Takara Bio, Inc.), and $1 \mu \mathrm{L}$ DNA template. Cycling conditions included an initial denaturation at $95^{\circ} \mathrm{C}$ for $2 \mathrm{~min}$ followed by 35 cycles with a denaturation step at $94.5^{\circ} \mathrm{C}$ for $1 \mathrm{~min}$, annealing at $56^{\circ} \mathrm{C}$ for $1 \mathrm{~min}$, extension at $72^{\circ} \mathrm{C}$ for $1 \mathrm{~min}$, followed by a final extension at $72^{\circ} \mathrm{C}$ for $5 \mathrm{~min}$. PCR products were purified with QIAquick spin columns (QIAGEN). The PCR reaction for EF1- $\alpha$ was carried out in a total volume of $50 \mu \mathrm{L}$ with all components added at $2 \times$ the volumes used in the reactions for the other loci. Thermal cycling was carried out as described for the other loci. The EF1- $\alpha$ PCR products were purified by electrophoresis in a $1 \%$ agarose gel, excision of the band and purification with the QIAEX II Gel Extraction Kit (QIAGEN). All DNA fragments were sequenced at the Cornell University Life Sciences Core Laboratories Centre using the Applied Biosystems Automated 3730 DNA Analyzer with Big Dye Terminator chemistry and AmpliTaq-FS DNA Polymerase. All gene regions were sequenced in both directions in at least one isolate. Sequences of EF1- $\alpha$, ITS, TUB2 and IGS for haplotype 1 (Table 2) are deposited in GenBank with accession numbers GQ255471, GQ255473, GQ255475, and GQ255476, respectively. Sequences of EF1- $\alpha$, ITS and TUB2 and from $E$. necator var. ampelopsidis isolates from $P$. quinquefolia are deposited under accession numbers GQ255474, GQ255470 and GQ255472, respectively.

Sequences were aligned and manually edited in SeqMan (DNASTAR, Inc). Haplotype networks were constructed for each locus and for combined multilocus sequences by statistical parsimony with the program TCS $1.21[60,61]$. Haplotype networks are preferable for intraspecific analyses because they allow for the coexistence of ancestral and derived haplotypes and account for recombination [62]. Alternative, most parsimonious networks are accounted for by this method as loops in the network. The networks were assembled based on an absolute distance matrix between haplotypes, i.e., the number of mutations separating each haplotype, with a parsimony probability of $95 \%$. The ancestral haplotype for each network was predicted based on rooting probability, which assesses the frequency of a particular haplotype and the number of linkages [33]. We also predicted the ancestral haplotype by maximum parsimony using E. necator var. ampelopsidis as an outgroup. Outgroup haplotypes could not be incorporated into the network with TCS due to high divergence.

\section{Estimates of diversity and tests of neutrality}

To compare diversity between source and introduced populations we estimated several population genetic parameters. They include: haplotype richness $\left(h_{\mathrm{R}}\right)$, the total number of haplotypes; Watterson's theta $\left(\theta_{\mathrm{w}}\right)$, which is a measure of nucleotide polymorphism equivalent to $2 N_{\mathrm{e}} \mu$ (in a haploid population) and an estimate of the effective population size [63]; and $\pi$, the pairwise nucleotide diversity [64]. Each parameter was estimated for the eastern US and introduced populations separately using DnaSP v5 [65]. To avoid the bias in diversity estimates caused by differences in sample sizes, we used bootstrapping to conduct rarefaction analysis [66]. For the eastern US population, we sampled a smaller numbers of individuals, with replacement, equal to the sample size of the introduced population and estimated $h_{\mathrm{R}}, \theta_{\mathrm{w}}$, and $\pi$. This was repeated 1000 times and the 
median estimates for each parameter were recorded. We conducted a one-tailed test to determine if eastern US populations were more diverse than introduced populations. $P$-values were estimated as the proportion of the null distribution that was less than the observed diversity estimate for the introduced population.

Tajima's $D$ [31] was calculated by using DnaSP v5 to test for departure from an equilibrium neutral model of evolution. Significant departures from neutrality were determined by permutation tests with 1000 replications.

\section{Population structure}

Differentiation among geographic regions, host habitats, and host species in eastern North America was estimated on combined multilocus sequences. For these analyses labrusca hybrids were grouped with $V$. labrusca rather than the vinifera hybrid group since they are most similar to V. labrusca (National Grape Registry http://ngr.ucdavis.edu. The nearest neighbour statistic $\left(S_{\text {nn }}\right)$ measures how often the most similar sequence or sequences ('nearest neighbour') is from the same designated population [67]. This statistic was selected for analyses because it has high power with small sample sizes. $S_{\mathrm{nn}}$ estimates the proportion of nearest neighbours that are from the same population versus from a different population. With two populations, for example, a value close to 1 suggests that the two populations are highly differentiated, because almost every sequence would be most similar to other sequences from the same population, whereas a value of 0.5 would be expected if populations are not genetically structured because the closest sequences would be most similar to those from either population with equal probability. We also estimated differentiation with $H_{\mathrm{ST}}$, a powerful measure of population subdivision that estimates $F_{\mathrm{ST}}$ among haplotypes [68]. Both $S_{\mathrm{nn}}$ and $H_{\mathrm{ST}}$ were calculated by using DnaSP v5. $P$-values were estimated by permutation tests with 1000 replications.

\section{Additional material}

Additional file 1: Table S1. Origin, collection date, and multilocus haplotypes of Erysiphe necator isolates.

\footnotetext{
Acknowledgements

We thank all of the generous collaborators who helped us collect E. necator by assisting in our sampling at field sites, by collecting powdery mildew samples or by sending us DNA. We especially thank Sam Anas, Omer Frenkel, W. Douglas Gubler and Turner Sutton for helping us locate and collect samples in the field; and Marie-France Corio-Costet, Paolo Cortesi, Franco Faretra, Monica Miazzi, Jean-Pierre Péros, Eileen Scott and Brenda Stummer for sending DNA. We also thank Paolo Cortesi, Lance CadleDavidson, Omer Frenkel, Rick Harrison and anonymous reviewers for helpfu comments on earlier drafts of this manuscript. This research was funded, in
}

part, by grants from Hatch projects NYC-145854 and NYC-153410, and a Research Travel Grant from the Cornell University Graduate School to MTB.

\section{Authors' contributions}

MTB participated in the design of the study, conducted the research, analyzed the data, interpreted the results, and wrote the manuscript. MGM conceived the study, participated in the design of the study, performed some of the analyses, assisted with interpreting the results, and critically revised drafts of the manuscript. Both authors read and approved the final manuscript.

Received: 26 January 2010 Accepted: 1 September 2010

Published: 1 September 2010

\section{References}

1. Milgroom MG, Wang K, Zhou Y, Lipari SE, Kaneko S: Intercontinental population structure of the chestnut blight fungus, Cryphonectria parasitica. Mycologia 1996, 88:179-190.

2. Nei M, Maruyama T, Chakraborty R: The bottleneck effect and genetic variability in populations. Evolution 1975, 29:1-10.

3. Dlugosch KM, Parker IM: Founding events in species invasions: genetic variation, adaptive evolution, and the role of multiple introductions. $\mathrm{Mol}$ Ecol 2008, 17:431-449.

4. Petit RJ, Aguinagalde I, de Beaulieu J, Bittkau C, Brewer S, Cheddadi R, Ennos R, Fineschi S, Grivet D, Lascoux M, Mohanty A, Müller-Starck G, Demesure-Musch B, Palmé A, Martín JP, Rendell S, Vendramin GG: Glacial refugia: hotspots but not melting pots of genetic diversity. Science 2003, 5625:1563-1565.

5. Genton BJ, Shykoff JA, Giraud T: High genetic diversity in French invasive populations of common ragweed, Ambrosia artemisiifolia, as a result of multiple sources of introduction. Mol Ecol 2005, 14:4275-4285.

6. May GE, Gelembiuk GW, Panov V, Orlova M, Lee C: Molecular ecology of zebra mussel invasions. Mol Ecol 2006, 15:1021-1031.

7. Pringle A, Adams Rl, Cross HB, Bruns TD: The ectomycorrhizal fungus Amanita phalloides was introduced and is expanding its range on the west coast of North America. Mol Ecol 2009, 18:817-833.

8. Goodwin SB, Cohen BA, Fry WE: Panglobal distributions of a single clonal lineage of the Irish potato famine fungus. Proc Natl Acad Sci 1994, 91:11591-11595.

9. Eckert CG: The loss of sex in clonal plants. Evol Ecol 2001, 15:501-520

10. Milgroom MG, Sotirovski K, Spica D, Davis JE, Brewer MT, Milev M, Cortesi P: Clonal population structure of the chestnut blight fungus in expanding ranges in southeastern Europe. Mol Ecol 2008, 17:4446-4458.

11. Weltzien HC: Geographical distribution of powdery mildews. In The powdery mildews. Edited by: Spencer DM. London: Academic Press; 1978:

12. Large EC: The Advance of the Fungi New York: Henry Holt and Co 1940.

13. Lepik EE: Gene centers of plants as sources of resistance. Annu Rev Phytopathol 1970, 8:323-344.

14. Lenné JM, Wood D: Plant diseases and the use of wild germplasm. Phytopathol 1991, 29:35-63.

15. Smith RE: Grape mildew as viewed in the early agricultural press of California. Plant Dis Rep 1961, 45:700-702.

16. Emmett RW, Wicks TJ, Magarey PA, Madge DG: Recent advances in grapevine powdery mildew management. Australian and New Zealand Wine Industry Journal 1990, 5:213-217.

17. Pearson RC, Gadoury DM: Cleistothecia the source of primary inoculum for grape powdery mildew in New York USA. Phytopathology 1987, 77(11):1509-1514.

18. Pearson RC, Gaertel W: Occurrence of hyphae of Uncinula necator in buds of grapevine. Plant Dis 1985, 69:149-151.

19. Délye C, Laigret F, Corio-Costet MF: RAPD analysis provides insight into the biology and epidemiology of Uncinula necator. Phytopathology 1997 87:670-677.

20. Evans KJ, Whisson DL, Stummer BE, Scott ES: DNA markers identify variation in Australian populations of Uncinula necator. Mycol Res 1997, 101:923-932

21. Stummer BE, Zanker T, Scott ES, Whisson DL: Genetic diversity in populations of Uncinula necator: Comparison of RFLP- and PCR-based approaches. Mycol Res 2000, 104:44-52. 
22. Miazzi M, Hajjeh H, Faretra F: Observations on the population biology of the grape powdery mildew fungus Uncinula necator. J Plant Pathol 2003, 85:123-129.

23. Péros JP, Troulet C, Guerriero M, Michel-Romiti C, Notteghem JL: Genetic variation and population structure of the grape powdery mildew fungus, Erysiphe necator, in southern France. Eur J Plant Pathol 2005, 113:407-416.

24. Núñez Y, Gallego J, Ponz F, Raposo R: Analysis of population structure of Erysiphe necator using AFLP markers. PlantPathol 2006, 55:650-656.

25. Montarry J, Cartolaro P, Delmotte F, Jolivet J, Willocquet L: Genetic structure and aggressiveness of Erysiphe necator populations during grapevine powdery mildew epidemics. Appl Environ Microbiol 2008, 74:6327-6332.

26. Délye C, Ronchi V, Laigret F, Corio-Costet MF: Nested allele-specific PCR primers distinguish genetic groups of Uncinula necator. Appl Environ Microbiol 1999, 65:3950-3954.

27. Amrani L, Corio-Costet MF: A single nucleotide polymorphism in the beta-tubulin gene distinguishing two genotypes of Erysiphe necator expressing different symptoms on grapevine. PlantPathol 2006, 55:505-512.

28. Montarry J, Cartolaro P, Richard-Cervera S, Delmotte F: Spatio-temporal distribution of Erysiphe necator genetic groups and their relationship with disease levels in vineyards. Eur J Plant Pathol 2009, 123:61-70.

29. Stummer BE, Scott ES: Detection of novel genotypes in progeny from a controlled cross between isolates of Uncinula necator belonging to distinct phenetic groups. Australas Plant Pathol 2003, 32:213-218.

30. Braun U, Takamatsu S: Phylogeny of Erysiphe, Microsphaera, Uncinula (Erysipheae) and Cystotheca, Podosphaera, Sphaerotheca (Cystotheceae) inferred from rDNA ITS sequences - some taxonomic consequences. Schlechtendalia 2000, 4:1-33.

31. Tajima F: Statistical methods to test for nucleotide mutation hypothesis by DNA polymorphism. Genetics 1989, 123:585-595.

32. Templeton AR, Routman E, Phillips CA: Separating population structure from population history: a cladistic analysis of the geographical distribution of mitochondrial DNA haplotypes in the tiger salamander, Ambystoma tigrinum. Genetics 1995, 140:767-782.

33. Castelloe J, Templeton AR: Root probabilities for intraspecific gene trees under neutral coalescent theory. Molec Phylogenet Evol 1994, 3:102-113.

34. Salmon ES: A monograph of the Erysiphaceae. Mem Torrey Bot Club 1900 9.

35. Balloux F, Lehmann $L$, de Meeûs $T$ : The population genetics of clonal and partially clonal diploids. Genetics 2003, 164:1635-1644.

36. Goyeau H, Halkett F, Zapater M, Carlier J, Lannou C: Clonality and host selection in the wheat pathogenic fungus Puccinia triticinia. Fungal Genetics and Biology 2007, 44:474-483.

37. Downie DA: Locating the sources of an invasive pest, grape phylloxera, using a mitochondrial DNA gene genealogy. Molecular Ecology 2002, 11:2013-2026.

38. Gobbin D, Rumbou A, Linde CC, Gessler C: Population genetic structure of Plasmopara viticola after 125 years of colonization in European vineyards. Mol Plant Pathol 2006, 7:519-531.

39. Pinney $\mathrm{T}$ : A history of wine in America: from the beginnings to prohibition Berkeley, CA: University of California Press 1989.

40. Wyand RA, Brown JKM: Genetic and forma specialis diversity in Blumeria graminis of cereals and its implications for host-pathogen co-evolution. Mol Plant Pathol 2003, 4:187-198.

41. Inuma T, Khodaparast SA, Takamatsu S: Multilocus phylogenetic analyses within Blumeria graminis, a powdery mildew fungus of cereals. Mol Phylogenet Evol 2007, 44(2):741-751.

42. Gadoury DM, Pearson RC: Heterothallism and pathogenic specialization in Uncinula necator. Phytopathology 1991, 81:1287-1293.

43. Bucheli $E$, Gautschi B, Shykoff JA: Differences in population structure of the anther smut fungus Microbotryum violaceum on two closely related host species, Silene latifolia and S. dioica. Mol Ecol 2001, 10:285-294.

44. Dopman EB, Pérez L, Bogdanowicz SM, Harrison RG: Consequences of reproductive barriers for genealogical discordance in the European corn borer. Proc Natl Acad Sci USA 2005, 102:14706-14711.

45. Frenkel O, Brewer MT, Milgroom MG: Variation in pathogenicity and aggressiveness of Erysiphe necator from different Vitis species and geographic origins in the eastern United States. Phytopathology.
46. Barker CL, Donald T, Pauquet J, Ratnaparkhe MB, Bouquet A, AdamBlondon AF, Thomas MR, Dry I: Genetic and physical mapping of the grapevine powdery mildew resistance gene, Run1, using a bacterial artificial chromosome library. Theor Appl Genet 2005, 111:370-377.

47. Couch BC, Fudal I, Lebrun MH, Tharreau D, Valent B, van Kim P, Notteghem JL, Kohn LM: Origins of host-specific populations of the blast pathogen Magnaporthe oryzae in crop domestication with subsequent expansion of pandemic clones on rice and weeds of rice. Genetics 2005, 170:613-630.

48. Crouch J, Tredway LP, Clarke BB, Hillman BI: Phylogenetic and population genetic divergence correspond with habitat for the pathogen Colletotrichum cereale and allied taxa across diverse grass communities. Mol Ecol 2009, 18:123-135.

49. Galet P: A Practical Ampelography: Grapevine Identification Ithaca, New York: Cornell University Press 1979.

50. Staudt G: Evaluation of resistance to grapevine powdery mildew (Uncinula necator Schw. Burr., anamorph Oidium tuckeri Berk.) in accessions of Vitis species. Vitis 1997, 36:151-154.

51. Olmo HP: The potential role of (vinifera $\times$ rotundifolia) hybrids in grape variety improvement. Experientia 1986, 42:921-926.

52. Olmo HP: Grapes. In Evolution of Crop Plants. Edited by: Smart J, Simmonds MW. Harlow, UK: Longman Group; , 2 1995:485-490.

53. Pearson RC, Gadoury DM: Powdery Mildew of Grape. In Plant Diseases of International Importance. Edited by: Kumar J, Chaube HS, Singh US, Mukhopadhyay AN. Englewood Cliffs, NJ: Prentice Hall; 1992:III:129-146.

54. Zohary D, Spiegel-Roy P: Beginnings of Fruit Growing in the Old World. Science 1975, 187:319-327.

55. Pearson RC, Goheen AC: Compendium of Grape Diseases Minneapolis, MN: APS Press 1988.

56. Evans KJ, Whisson DL, Scott ES: An experimental system for characterizing isolates of Uncinula necator. Mycol Res 1996, 100:675-680.

57. Walsh PS, Metzger DA, Higuchi R: Chelex 100 as a medium for simple extraction of DNA for PCR-based typing from forensic material. BioTechniques 1991, 10:506-513.

58. Hirata T, Takamatsu S: Nucleotide sequence diversity of rDNA internal transcribed spacers extracted from conidia and cleistothecia of several powdery mildew fungi. Mycoscience 1996, 37:283-288.

59. Carbone I, Kohn LM: A method for designing primer sets for speciation studies in filamentous ascomycetes. Mycologia 1999, 91:553-556.

60. Clement M, Posada D, Crandall KA: TCS: a computer program to estimate gene genealogies. Mol Ecol 2000, 6:1657-1659.

61. Templeton AR, Crandal AK, Sing CF: A cladistic analysis of phenotypic associations with haplotypes inferred from restriction endonuclease mapping and DNA sequence data. III. Cladogram estimation. Genetics 1992, 132:619-633

62. Posada D, Crandall KA: Intraspecific gene genealogies: trees grafting into networks. TREE 2001, 16:37-45.

63. Watterson GA: On the number of segregating sites in genetical models without recombination. Theor Pop Biol 1975, 7:256-276.

64. Nei M: Molecular Evolutionary Genetics New York: Columbia Univ. Press 1987.

65. Librado P, Rozas J: DnaSP v5: A software for comprehensive analysis of DNA polymorphism data. Bioinformatics 2009, 25:1451-1452.

66. Grünwald NJ, Goodwin SB, Milgroom MG, Fry WE: Analysis of genotypic diversity data for populations of microorganisms. Phytopathology 2003, 93:738-746.

67. Hudson RR: A new statistic for detecting genetic differentiation. Genetics 2000, 155:2011-2014

68. Hudson RR, Slatkin M, Maddison WP: Estimation of levels of gene flow from DNA sequence data. Genetics 1992, 132:583-589.

doi:10.1186/1471-2148-10-268

Cite this article as: Brewer and Milgroom: Phylogeography and population structure of the grape powdery mildew fungus, Erysiphe necator, from diverse Vitis species. BMC Evolutionary Biology 2010 10:268. 